\title{
One Profession-but not one Oath; a new survey revisiting the Chiropractic Oaths*
}

\author{
Marshall N Deltoff DC DACBR FCCR(C) \\ Faculty, Barcelona College of Chiropractic, \\ Barcelona, Spain
}

\begin{abstract}
Thirty years ago, in 1988, we undertook the first formal academic examination of the Chiropractic Oath: its development and an analysis of its component parts. At that time, we studied 38 oaths from 25 different chiropractic colleges. Various themes and topics were identified, some of which occurred consistently, and others appearing but once or twice. With the recent global expansion of our profession to new schools in many more countries, the oaths presently used at chiropractic colleges worldwide were subjected to the same analysis for comparison. 42 oaths were obtained from the 45 institutions currently listed on the World Federation of Chiropractic website.

Increased access, both electronically and in person, has enabled our academic institutions to communicate and relate at a level unimaginable thirty years ago. This increasing college interaction is one aspect of our progressive unity. It is proposed that consideration be given to the development of a single Chiropractic Oath as a tangible example of this professional unity.
\end{abstract}

\footnotetext{
* Este artículo obtuvo, el pasado año académico 2017-2018, el Premio María Cristina, en su quinta edición, en la modalidad de Quiropráctica, patrocinado por el Banco Santander. El jurado calificador estuvo conformado por: $\mathrm{D}^{\mathrm{a}}$. Ana Paula Albuquerque Facchinato Campos (Presidenta), Coordinadora de la Formación Clínica. Facultad de Quiropráctica de Los Ángeles. Southern California University of Health Sciences; D. Danilo Messa da Silva, Decano de Quiropráctica, Universidad Feevale, Novo Hamburgo, Brasil; D. Fernando Redondo Moreira Azevedo, Decano de Quiropráctica de la Universidade Anhembi-Morumbi, Sao Paulo, Brasil, y D. Ricardo Fujikawa (Secretario), Director de Estudios de Quiropráctica en el RCU Escorial María Cristina.
} 



\section{INTRODUCTION}

The chiropractic oath is more than a promise. It declares a code of ethical behaviour, subscribed to by the new graduate, that defines our profession. It is the foundation of a social contract between the new doctor and patients, colleagues, other professionals and society in general. The commonalities and differences uniquely chronicled in the chiropractic oaths reflect the historic and current diversity of the doctors that make up our great profession.

\section{METHOD}

In the initial 1988 study, each chiropractic college was asked to provide the authors with a copy of its (then) current chiropractic oath, as well as any other oaths the college had used in the past. In addition, it was requested that any similar information on colleges which have suspended operation be provided from library archives. Individual practitioners known to have been associated with colleges which were no longer operational were also contacted as potential resources. Of the 23 existing colleges in 1988, only Japan College of Chiropractic did not respond, providing a $96 \%$ response rate. In total, 38 oaths from 25 chiropractic colleges were received for analysis.

The number of schools has now grown to 45 . This marked globalization of chiropractic education is concurrent with a quantum leap in the ability to interact, communicate and dialogue in ways barely imaginable 30 years ago. The existing schools were requested to provide a copy of their current chiropractic oath. All 45 schools responded, yielding a 100\% response rate, and provided 42 oaths for analysis. Again, as in 1988, all oaths received were utilized. The nonEnglish oaths were either accompanied by English translations provided by the school, or were translated by native speakers or professional translators.

The components of the oath were divided into categories: (1) G-d; (2) school name; (3) chiropractic terminology; (4) patient interaction; and (5) professional attitude. Categories 3, 4 and 5 were then further subdivided into specific topics 
appearing in the oaths. (Table 1) An additional subcategory was added for this current study: 4f: no discrimination. The frequency of these topics is shown in Figure 1 (comparing their frequency with the 1988 study). The specific topics appearing in each individual oath are summarized in Table 2.

Two of the oaths are not provided by the academic institutions. The oath recited by UQTR graduates is administered, not by the school itself, but rather by the profession's regulatory body in Quebec, L'Ordre des Chiropraticiens du Quebec. Similarly, it is the Chiropractic Association of South Africa that administers its oath to graduates of that country's two chiropractic institutions.

\section{RESULTS/DISCUSSION}

\section{$G-d$}

Pledging, swearing or affirming before G-d was a common component back in 1988, appearing in 74\% of submitted oaths in the original study. G-d was referred to as "the Creator" in the Logan Basic College oath of 1939. Thirty years later, only $40 \%$ of oaths mention G-d. Is this huge decrease perhaps an indicator of a secularization of professional education, and, by extension, society in general? The following schools had reference to G-d back in 1988, but have since removed that reference: Anglo-European College, Life University and New York College. Palmer College and Sherman College removed the reference to G-d in 1978. Interestingly, Logan College, reversing the trend, added a reference to G-d to its current oath in 1987. Western States College, to this day, still provides for an optional referral to G-d. Bahcesehir University graduates speak of "the architect of the universe". Of note is a difference between the inclusion of G-d in the current oaths of US schools (65\%) vs. non-US schools, at only $28 \%$.

\section{School name}

In 1988, only Canadian Memorial and Western States actually mentioned the school's name in their oaths. Currently, $19 \%$ of the colleges mention the school's name. Seven schools use the more generic "alma mater"; interestingly, all are in the United States. Macquarie University grads mention only "my university".

\section{Chiropractic terminology}

Although the profession has always acknowledged chiropractic as an art, science and philosophy, by far 'chiropractic art' or 'chiropractic healing art' 
is the most consistently used in the chiropractic oaths; (82\% in 1988, and $69 \%$ today). Science (39\% in 1988 and $40 \%$ in 2018) and chiropractic philosophy (32\% in1988 and 43\% in 2018) were significantly less popular, although each showed an increase in the current study. Both the 1988 oath of Sherman College of Straight Chiropractic and the current oath of New Zealand College refer to "enriching philosophical understanding" and "enhancing artistic ability ", while omitting any mention of science.

The use of 'Natural laws' was present in $37 \%$ of oaths in 1988 and in only $21 \%$ of today's oaths. The oath at Canadian Memorial College has always included reference to the "Vis Medicatrix Naturae" Use of hands (11\% in 1988; $5 \%$ in $2018)$ and Innate (13\% in 1988) were rare.

'Innate' was actually only mentioned in the Canadian Memorial and Western States oaths in 1988. Today, only the oath of Canadian Memorial College still contains the word 'innate'. Sydney College (1988), and Macquarie University (2018) refer to ".. the body's inherent capacity for recovery". Barcelona College graduates (2018) mention “... inborn endowments".

The chiropractic concept of 'dis-ease' was only used by Canadian Memorial from 1945-54. The following year, the hyphen was dropped; the new college administration that year likely brought on that change in the oath. 'Vertebral subluxation' only appears twice; first, in the post-1978 oath of Sherman College of Straight Chiropractic, remaining a part of the current oath of Sherman College, and second, in New Zealand College's oath. Both state: “... honored with the opportunity to be instrumental in the correction of vertebral subluxations". (The only difference is the British spelling of 'honoured' in New Zealand as a Commonwealth country).

The ancient historic bond with medicine is represented by the use of Hippocrates' name in the oaths of Barcelona College and Canadian Memorial College: “ . . . and with this torch of knowledge fashioned by Hippocrates, I will light the way to the understanding of those Natural Laws which preserve the human body as a fitting temple for the soul (of man) ".

The oath of National College from 1935 until at least 1949 did not contain any reference to 'chiropractic' at all, but rather mentioned 'this drugless healing art". National College did adopt the CCE oath in 1972, which did mention “... this chiropractic healing art ". However, today, National College graduates once more do not mention chiropractic in their oath, instead pledging to maintain "...the honor and the noble traditions of the healing professions ". The graduates of Australia's oldest chiropractic school, Macquarie University, 
(formerly Sydney College), do not mention the word 'chiropractic' when they recite their oath. Additionally, the current oaths of Anglo-European College, McTimoney College, Universidad Estatal del Valle de Ecatepec and Universidad Estatal del Valle de Toluca also have no reference to 'chiropractic'; AngloEuropean College removed 'chiropractic' from its oath sometime after 1988. The Welsh Institute oath, used until 2017, also contained no reference to chiropractic, but rather used "...the art of healthcare...".

\section{Patient interaction}

Of all components of the oath, the 'relief of suffering and of disease' appeared most often in the 1988 study at $87 \%$. This certainly seems logical as it constitutes the ultimate raison d'etre of our profession. Today, in a surprising observation, only $36 \%$ of oaths contain some reference to relief of suffering and disease.

'Keeping of a patient's confidence' is considered so important that it ranked second overall in frequency in 1988 (84\%) and first overall in 2018 (78\%). This phrase definitely alludes to our position of great responsibility; that chiropractors are, in fact, professional confidants. The graduates of the nowdefunct Pasadena College would state "that I will not reveal to anyone anything revealed to me in the course of my work, save with full knowledge and permission of the patient involved". Sydney College (1959-90) merged with Macquarie University in 1990, and all graduates, pre-and post-merger, pledged and continue to pledge to "...guard their secrets with scrupulous honour and fidelity". Graduates of the University of Central Chile promise to "save and respect professional secrecy”. Welsh Institute graduates, until 2017, would include “... respecting and protecting confidential information" as part of their oath.

National College grads from at least 1935 through 1949 promised that "Whatever in connection with my professional practice, or not in connection with it, I may see or hear in the lives of men and women which ought not to be spoken abroad, I will not divulge, reckoning that all such should be kept secret ". Today, National grads today go so far as to say "I will respect the secrets that are confided in me, even after the patient has died ".

Hand in hand with keeping a patient's confidence is the promise to generally 'refrain from wrongdoing' (76\% in $1988 ; 64 \%$ in 2018 ), also a very common theme for a professional pledge, promise or oath.

In the 1950's graduates of the Chiropractic Institute of New York would pledge to "... abstain from all intentional mischief and harm ". Logan College 
graduates in the 1980's promised that "I will not misrepresent myself or my profession to others and will never use my knowledge of chiropractic to cause harm or injury to any person ".

The graduates of Sydney College (and now Macquarie University) promise to "... not engage in those practices which will in any way bring shame or discredit upon myself or my profession". Current graduates at Southern California University pledge "to practice ethically and with honesty". A number of oaths, both past and present, mention "to abstain from whatever is deleterious and mischievous" (CCE oath 1972, Texas College and University of Bridgeport today), or "to abstain from whatever is harmful or unethical" (Northwestern University since 1984). Palmer College and Palmer College-West grads currently promise to "... not violate that which is moral and right," as did the graduates of Pennsylvania College of Straight Chiropractic. The graduates of the French school promise "to abstain from all intervention which may be dangerous...". Welsh Institute graduates would promise to "...not abuse my professional position and at all times I will be honest and trustworthy".

'Serving humanity' ( $47 \%$ in $1988 ; 26 \%$ in 2018 ) is referred to in the oath shared by Palmer College and Palmer College-West, with the phrase " ... help to grow in service to the benefit of all humanity". Until sometime in the 1980's, Cleveland College-KC grads would"... champion the right of all humanity to enjoy the benefits and blessings of chiropractic ". National grads today put a somewhat different spin on serving humanity by stating "I will not use my medical knowledge contrary to the laws of humanity, even under threat ". "To stand ready at all times to serve humanity" pledge current New York College and Northwestern University grads.

\section{Gender issues and sexism in the chiropractic oath}

One of the more contentious topics considered here is the practice of only referring to men in the oath. This circumstance was present overall in $68 \%$ of the oaths received in 1988 but only $26 \%$ of oaths used today. Refreshingly ahead of its time was the oath used at National College from 1935 until at least 1949. While it did conclude with the commonly found 'respected by all men at all times', it was the only oath which actually mentioned women.

Canadian Memorial has changed its oath sometime between 1988 and today, by removing "of man" from the phrase "...fitting temple for the soul of man", and by substituting "...stand ready to serve my fellow man" with "...stand ready to serve humanity". Other colleges that no longer have sexist language include Anglo-European College, New York College, Life College, Life College-West, 
Logan College, National College, Southern California University, Northwestern, Palmer (removed in 1978), and Western States (removed in 1982). Sherman College, the Danish schools, Lincoln College, Pasadena College, Sydney College/ Macquarie University and Palmer College-West never had sexist language in their oaths.

Sexist language in a chiropractic oath should never have been acceptable, and it can be noted that steps have been taken by many of the colleges to correct their oaths over the past decades, demonstrating fairness, inclusion and respect to the increasing number of women doctors.

The 1972 oath adopted by the Council of Chiropractic Education used at the convocation ceremonies at Los Angeles, National, New York, Parker and Texas Colleges back in 1988 contained sexist language. Additionally, the 1988 oaths of Anglo-European, Canadian Memorial, Cleveland -KC, Cleveland-LA, Institut Francais, Life, Life-West, Logan, Phillip Institute and Pennsylvania Colleges also each contained at least one exclusively masculine reference. Although many of the oaths have definitely improved in this regard, today, the oaths of Bahcesehir University, Barcelona College, Cleveland College, Hanseo University, Institut Franco-Europeen, Madrid College (“... consider my colleagues as brothers... "), Parker College, Texas College, Universidad Estatal del Valle de Ecatepec, Universidad Estatal del Valle de Toluca and Universidad Veracruzana still contain a reference to men only.

For this current study, a new category was added to the oath analysis, that of not discriminating against patients. This is a fairly popular concept in the oaths, appearing in $60 \%$, and phrased in a variety of ways.

The Welsh Institute and McTimoney College oaths include "I will never discriminate unfairly against patients or colleagues". Feevale University graduates add simply "... without any form of discrimination". “... without distinction of race, creed or colour", state the Canadian Memorial College and D'Youville College graduates, as well as those at Anglo-European College, Northwestern University, Parker University, Texas College, University of Bridgeport, and grads from both South African schools. Southern California University's oath changes the order to "race, color or creed". The Barcelona College oath has changed that to "... without distinction of race, creed or beliefs". The Madrid College graduates pledge to "Always respect political and religious beliefs, nationalities, races, and social and economic levels, ensuring that they avoid interfering between my professional services and my patients". Sherman College graduates promise that "My best service will be available to all, regardless of their cultural, racial or religious 
background, or their ability to pay". The first graduates of the Keiser University program, scheduled to graduate next within the year, will include in their oath "I will respect... without regard to gender, race, national origin, religion or sexual orientation". National University has the most inclusive list in its oath, stating "I will not permit considerations of age, disease or disability, creed, ethnic origin, gender, nationality, political affiliation, race, sexual orientation, social standing or any other factor to intervene between my duty and my patient". Institut Francais graduates promise to “... provide bountiful help at all times to my neighbour, without distinction of race or belief". The New Zealand College oath states "My best service will be available to all, regardless of their cultural, racial or religious background, or their ability to pay".

\section{Professional attitude}

Forty-two percent of all oaths in the 1988 study mentioned having a 'positive regard for colleagues' while today the percentage has risen to $48 \%$. This addresses the issue of respecting other chiropractors and promoting professional unity and harmony. This is perhaps most explicitly stated in the 1986 Logan College oath: "I will not denigrate those in my profession who choose to use methods different from mine". National College grads today maintain that "my colleagues will be my sisters and brothers". Murdoch University grads state that "I will regard my fellow health professionals with courtesy and good faith". A Macquarie University graduate promises that "I will endeavor to work in accord with my colleagues in a spirit of progressive cooperation and never by word or act cast imputations upon them or their rightful practices".

Respect for teachers, commonly referred to as 'those who taught me this chiropractic healing art', was a moderately popular inclusion in the 1988 study $(53 \%)$, and reduced today to $38 \%$. While the oath is a professional promise, it is recited as a final act within the academic environment, and thus, respect for teachers ties in well with the transition from student to practitioner. The Institut Franco-Europeen graduates pledge to "always respect the pioneers of the chiropractic art, and those who taught it to me".

With the understanding that every graduate is, in effect, an eternal student, several of the oaths (34\% in 1988 which has increased to $60 \%$ today) include phrases in which the graduate pledges to 'keep an open mind', 'continue to learn' and 'improve his/her knowledge'. These include: "I will keep an open mind regarding the progress of my profession..." (Columbia Institute 1966, Life College, Life College West, Logan College 1987+, Palmer College, Sherman College 1973-78); "I shall keep abreast of the advancements in my profession" (Lincoln College); "I will actively continue to learn and to improve my skills" 
(Logan College 1986); I will keep an open mind regarding the changes in my profession... "(Pennsylvania College) and "I pledge to... constantly maintain my knowledge" (Institut Franco-Europeen). McTimoney College graduates humbly admit that "Recognizing the limits of my competence, I will keep my professional skills and knowledge up to date". A New York College graduate pledges that "through lifelong learning I will keep my skills and mind sharp". At Western States University, grads promise that "I will continue learning throughout my life so that I may provide for the good of my patients". The graduates of Murdoch University pledge that "I will continually and judiciously improve my knowledge and skill". Welsh Institute graduates, until administration of their oath ceased in 2017, would pledge “... will look to contemporary science and evidence for what I do...".

Improving knowledge and skill is an important component of the promise made by a chiropractor at graduation. Any proposed universally accepted chiropractic oath should include a phrase to that effect. Even as early as 1948, Palmer College had the foresight to comment on advancement in the profession as part of its oath. It is the graduates' responsibility to their patients to remain contemporary in academic and clinical knowledge in order to best serve them. Thus, 'improving knowledge' would seem to be a proper inclusion in the graduation pledge.

The Chiropractic Institute of New York oaths (1956-1960) even mention "to impart, unreservedly, instruction in the Art and Science of Chiropractic to my colleagues, but to none others". This unique phrase ties in the idea of cooperation and regard for colleagues with the concept chiropractors can teach each other as well as learn from each other.

More than half of the oaths in the original study (55\%) mention 'living up to the principles' of the profession. This figure has gone down to $48 \%$ today. There is a variety of ways in which this is stated: “... insofar as my science is in the highest precepts of my alma mater and harmonious with the Vis Medicatrix Naturae" (Canadian Memorial College); "To live up to the highest principles of my profession" (Cleveland-KC 1980+). "To always live up to the high principles of my profession (Cleveland-KC pre-1956, Cleveland-LA 1950+). "I will observe and practice every acknowledged rule of professional conduct in relation to my profession, my patient, my colleague and myself " (Bahcesehir University -present, Columbia Institute 1966, Durban University of Technology -present, Hanseo University -present, International Medical University -present, Life College, Life College-West, Logan University 1987-present, Murdoch University -present, Pennsylvania College 1977-1995, Sherman College 19731978, University of Johannesburg -present, Universidad Veracruzana-present). 
"To hold my profession and the practice of my profession to the height for which its value provides" (Logan Basic College 1939); "I will strive to bring credit to... my profession" (Logan College 1986); "I will adhere to the code of ethics espoused by the chiropractic profession" (Palmer College 1983-present, Palmer College-West post 1988). "That I will adhere faithfully to the principles and practice of Chiropractic Art and teachings" (Pasadena College 1974-1995).

'Protecting chiropractic' is a topic found in $13 \%$ of oaths in 1988; this has increased to $17 \%$ in 2018 . The oaths of Columbia Institute diplomatically stated, "I will scrupulously maintain the dignity and honor of my profession at all times. "Palmer College graduates $(1983+)$ now say, "I will seek to preserve the integrity of my profession... "Each Cleveland College-KC graduate (pre1957) defiantly pledged "to protect my science from all enemies". From 1950 until the school closed in 2011, every Cleveland College-LA graduate promised to "protect my science"; this phrase is still recited today by Cleveland College-KC grads. Graduates of the University of Central Chile state"... to keep unharmed, by all means at my disposal, the honor and noble traditions of the Chiropractic profession". "I will do anything within the law to protect the rights of chiropractic as an autonomous profession "declare the graduates of Turkey's chiropractic school. National College graduates state"... will maintain by all means in my power, the honor and the noble traditions of the healing professions ", oddly not specifically mentioning chiropractic.

'Referral of patients' is mentioned in only $5 \%$ of the oaths in the 1988 study. This topic reminds graduates of the limitations of chiropractic. In the current study, the percentage has more than doubled to $11 \%$. Perhaps this reflects a lessening of the historic animosity between chiropractic and medicine, with greater interprofessional dialogue and cooperation. A new Lincoln College doctor would promise "that I shall call consultants for all cases where such consultation will benefit the patient. That I shall not hesitate to refer patients to practitioners of other professions if in my opinion such advice will benefit those patients". The Chiropractic Institute of New York oath, with regard to medical referral, goes so far as to state, "I will not use the knife, but will give place to craftsmen in the use thereof ". The McTimoney College oath states that graduates"... will work with colleagues in the ways that best serve patients". Bahcesehir University grads say that "I will make use of all allied health care providers and refer my patient if the referral shall serve to the best interest of the patient ". Western States University graduates promise that "I will collaborate with other health care professionals to promote public health and wellness ". The Welsh Institute oath alluded to referral with "I will do what is best for my patients, and in this recognize my own limits of competence and scope, as well as the expertise of others ". 
'Financial gain' is a component only of the Pasadena College oath in the 1988 paper; this is a rather peculiar topic for an oath to contain. It is specifically only mentioned once: "... I shall be rewarded with respect and financial reality “, and is alluded to earlier on in the oath: "... and will share with them the rewards which may come to me... "While 'financial reality' is one of the rewards for the hard-working, ethical practitioner, its inclusion in a professional oath may tarnish and detract from the altruistic spirit which makes it so special.

'Involvement in professional associations and/or the community' certainly allows the graduate to contribute and grow as a person and a professional. Both involve a degree of goodwill, commitment and selflessness. Macquarie University's oath states, "I will be ever vigilant in aiding the general welfare of the community, sustaining its laws and institutions ". It is the only existing oath which mentions contributing to the welfare of the community; it's been a phrase in its oath from back in the Sydney College era.

\section{Additional observations}

Interestingly and unfortunately, there are several institutions that do not currently administer a chiropractic oath at all. The chiropractic school at the University of Zurich, reported that "there is no special oath for the chiropractic students. They swear the regular human medicine oath ". (Manuela Lüber, Department Assistant and Deputy Head of Administration, School of Chiropractic Medicine, University of Zurich, personal communication, January 11, 2018). The Swedish College of Chiropractic (Skandinaviska Kiropraktorhogskolan) informed the author that "We don't have those kind of ceremonies in Sweden overall, and therefore not in our school either ". (Mikael Jansson, Skandinaviska Kiropraktorhogskolan, personal communication, October 18, 2018).

Brisbane's Central Queensland University has graduated two classes of chiropractors, and, according to Dr. Andrew Dane, Lecturer, School of Health, Medical and Applied Sciences, Central Queensland University, their students do not swear an oath either in clinic or at graduation (personal communication, November 16, 2018).

Dr. Michael Haneline, Director of the Center for Complementary and Alternative Medicine at International Medical University (IMU) in Kuala Lumpur, reported that "The University does not have an oath that is specific for the chiropractic program" (personal communication, October 22, 2018). The president of the Malaysian Association of Chiropractic, Dr. Wong Yi Kai, explained that the chiropractic graduates of IMU were using the Hippocratic 
oath upon enrollment in the chiropractic program, so the Association submitted a version of the chiropractic oath (used in this study) to the school. The oath was used only for the first two graduating classes, and then abandoned as "the IMU graduates of the second class do not see value in it" (personal communication, October 21, 2018).

The Welsh Institute of Chiropractic used a chiropractic oath at graduation ceremonies up until 2017. "The university decided to drop it; there are reasons for this and we are currently looking at alternatives ", explained Dr. David Byfield, Head of Clinical Services at the Welsh Institute (personal communication, October 25, 2018). He noted that Anglo-European College worked on the oath for the Welsh Institute. This oath was used in the current study.

Several chiropractic colleges have either never changed their oath or only minimally changed it. The original Danish Chiropractors' School, the first chiropractic college outside of North America, operated from 1948-51, and graduated only one class, on June 4, 1951. Its oath, with one minor modification ("practicing chiropractor" replaced with "my business as a chiropractor") is still used today by the chiropractic graduates of the University of Southern Denmark. The Institut Franco-Europeen has never changed its oath. Sydney College (1959-90) only changed the word "college" to "university" when it merged with Macquarie University in 1990.

\section{CONCLUSIONS}

\section{A single chiropractic oath}

In the early 1970s, the Council on Chiropractic Education in the US attempted to develop a single chiropractic oath. A committee gathered all of the oaths in use and drafted a composite oath. The colleges then all voted to adopt and use that oath. Unfortunately, the project was shelved when some of the colleges changed their minds and decided to continue to use their own individual oaths. (Leonard E. Fay, January 1988, personal communication). Texas College still uses this oath today. One of the schools that adopted the CCE oath, New York College uses a modified version of that oath, 'modernizing' some of the terminology. "To abstain from whatever is deleterious and mischievous" has been replaced by "...from unethical behavior"; "... to serve my fellow man" with "... to serve humanity"; "with purity I will... practice my art" with "with commitment to excellence will I practice my art"; and "I will keep inviolate..." with "I will hold in confidence...". The University of Bridgeport has never changed its oath, using the original CCE oath with 2 minor changes: 
“... to serve my fellow man/woman..." has replaced "...to serve my fellow man..."; and "... respected by all at all times" replaced "respected by all men at all times".

Parker College adopted the CCE oath from the beginning, and, with some 'modernization' of terminology, has essentially kept the same oath. 2018 grads pledge "that I will keep this oath and life commitment" replacing "...oath and stipulation"; "to abstain from whatever is deleterious and unethical "instead of "...deleterious and mischievous"; "I will not spare myself in providing my patients the care..." has replaced "... in rendering them the help..". Cleveland College-KC has adopted the oath that Cleveland College-LA had used from 1950 until it closed in 2011. That oath was written especially for Cleveland College by Dr. Leo Spears, founder of the Spears Chiropractic Hospital, in Denver, Colorado. Sherman College has also kept its oath virtually identical since 1978; it changed "straight chiropractor" to "chiropractor " in 2009, in keeping with the name change of the school back to its original name after "straight" was added in the late 1970's.

There are various themes which are common to many of the chiropractic oaths, regardless of college; at the same time, however, there are topics which are covered only by a handful of oaths.

Some of the chiropractic oaths draw phrases from the medical oath of Hippocrates. As mentioned, students of Malaysia's school of chiropractic at the International Medical University recite the Hippocratic Oath today upon entering the program. The Hippocratic Oath has been amended since its inception, and now consists of several versions. Medicine did attempt to modernize and unify a formal ethical code in 1948, following World War II, during which nazi medical doctors were notoriously complicit in violating all manners of morality and ethics. The World Medical Association then drafted and established the Declaration of Geneva, which appears to be a preferred replacement for the Hippocratic Oath.

Chiropractic colleges today interact with each other to an extent never before possible. Faculty cross-appointments, student educational and social exchanges, seminars, symposia, conventions and online access have all facilitated the breaking down of barriers, while promoting positive communication between the increasing number of our learning institutions worldwide. This increasing college interaction is a statement of our progressive unity. The global expansion of our profession's teaching institutions now sees chiropractic oaths recited on every continent, and, not only in English, but in Danish, French, Japanese, Korean, Portuguese and Spanish, with more to come. 
A tangible symbol of this positive global chiropractic dialogue would be the universal adoption of one, singular chiropractic oath. This would then be the Chiropractic Oath recited at all convocation ceremonies, at all of the schools, sanctioned by the various chiropractic educational accreditation bodies. Perhaps a committee could be assembled, with delegates invited from each chiropractic college; this committee could analyze and consider potential components of an 'ideal' oath, incorporating aspects of the different oaths from past and present. Several possible oaths might be drawn up and presented to the profession for further discussion. It is my hope that this paper will foster some positive interest in such a project.

\section{ACKNOWLEDGEMENTS}

My sincere thanks to Dr. Pablo Perez de la Ossa, Director of Research, Barcelona College of Chiropractic, for his valuable editorial assistance, to Mrs. Yocheved Deltoff and Ms Marina Perez de la Ossa for their translation skills, and to the chiropractic college administrators, alumni and students who helped in collecting all of the oaths.

\section{REFERENCES:}

- Smallie P. Getting the Chiropractic Show on the Road. 1985, Stockton, CA. Dye AA. The Evolution of Chiropractic. 1939, Philadelphia, privately published.

- Deltoff AB, Deltoff MN. One profession - one oath; a survey of the disparity of the chiropractic oath. Chiro History 1988; 8:20-6.

\begin{tabular}{|l|l|}
\hline \multicolumn{2}{|c|}{ TABLE 1: CHIROPRACTIC OATH COMPONENTS } \\
\hline 1 & G-d \\
\hline 2 & College name \\
\hline $3 \mathrm{~A}$ & Chiropractic Science \\
\hline 3B & Chiropractic Philosophy \\
\hline 3C & Chiropractic Art \\
\hline 3D & Innate \\
\hline 3E & Dis-ease \\
\hline 3F & Natural laws \\
\hline 3G & Use of hands \\
\hline 3H & Vertebral subluxations \\
\hline 3I & Hippocrates \\
\hline
\end{tabular}




\begin{tabular}{|l|l|}
\hline 3J & No mention of Chiropractic \\
\hline 4A & Relief of sick/disease/suffering \\
\hline 4B & Keeping of patient's confidence \\
\hline 4C & Refrain from wrongdoing \\
\hline 4D & Serve humanity \\
\hline 4E & Mentions men only \\
\hline 4F & Show no discrimination \\
\hline 5A & Regard for colleagues \\
\hline 5B & Respect for teachers \\
\hline 5C & Improving knowledge/keeping open mind \\
\hline 5D & Live up to principles of the profession \\
\hline 5E & Protect chiropractic \\
\hline 5F & Referral \\
\hline 5G & Financial gain \\
\hline 5H & Participate in community/associations \\
\hline
\end{tabular}

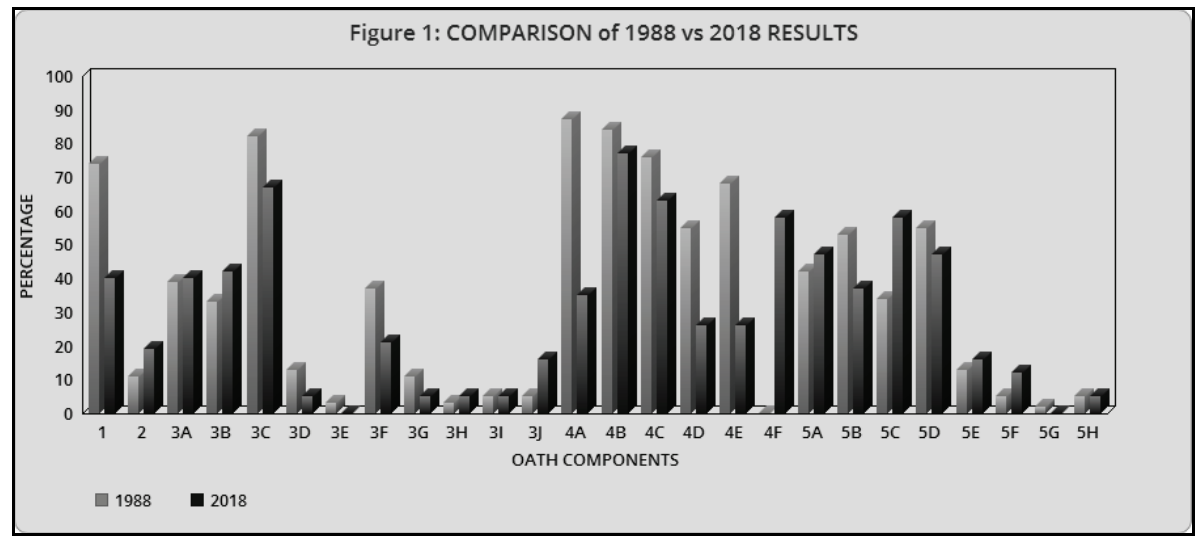







Reciting the Chiropractic Oath at New York, Canadian Memorial and Palmer Chiropractic Colleges
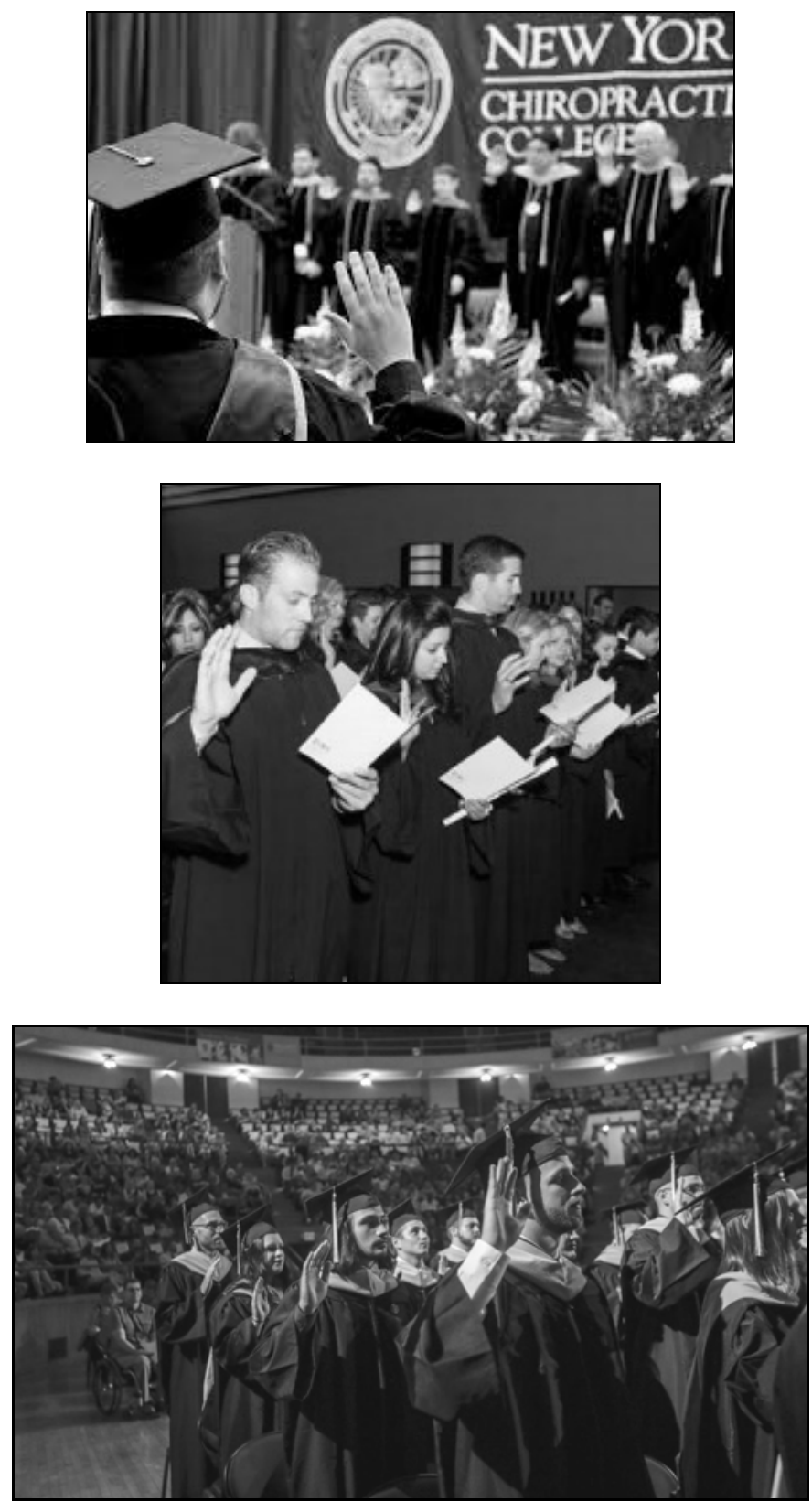